\title{
Developing Classroom Blog in Engineering Mathematics to Enhance Students Comprehension Ability
}

\author{
D. Rohendi, Purnawan \\ Departemen of Mechanical Engineering Education \\ Universitas Pendidikan Indonesia \\ Bandung, Indonesia \\ dedir@upi.edu
}

\begin{abstract}
Nowadays, the use of blog in daily activity is increasing, yet research of how the blog used in teaching is still a few. Further contribution of how the blog used toward learning result is limited. To overcome this problem, a research was conducted which aimed: 1) to develop the classroom blog in engneering mathematics; 2) to find out whether there is an improvement of student's comprehension ability in engineering mathematics or not; and 3) to find out how the students response after learning using classroom blog. The method of this research is research and development continued by quasi-experiment in limited implementation. Samples are taken from students of mechanical engineering of education department. Instruments used in this research are judgment sheets of testing media, pretest and post-test instrument, and questionnaire sheets. After developing and testing it, the test toward classroom blog acquired result that the classroom blog is considered worthy, whereas hypothesis testing acquired result that the use of classroom blog increased the student's comprehension ability in engineering mathematical. This is shown by index of normalized gain for 0.69 on students who implement classroom blog on intermediate criterion. Based on questionnaire, it acquired result that the students' response toward classroom blog developed is favorable.
\end{abstract}

Keywords-classroom blog, engineering mathematics, students comprehension ability, implementation.

\section{INTRODUCTION}

Engineering mathematics is one of the subjects exists in the curriculum of Mechanical Engineering of Education Department. This subject is very important, since many mathematical concepts are needed. In addition, mathematical concept is a concept that is widely used to help other science. Kline (1973) (in [1]) stated that: "Mathematics is not an autonomous knowledge that can be perfect by itself, but was mainly to help people in understanding and mastering the problems of social, economic, and nature."

Engineering concept that requires mathematical concepts are thermodynamics, mechanics engineering and fluid, kinematics, automotive, manufacturing, designing, modeling, simulation, and more. There are still obstacles in understanding the mathematical concepts that should be implemented in the fields. Moreover, students of Mechanical Engineering of Education Department not only originated from high school graduates, but also from vocational high school. In general, students of vocational high school need more time to understand engineering mathematics concepts instead of high school students. Student learning outcomes during researcher lectures in engineering mathematics subject are less encouraging. According to the results of study in the previous semester, $80 \%$ of students got $\mathrm{C}, 5 \%$ got $\mathrm{B}$ and $5 \%$ got $\mathrm{A}$, while the remaining $10 \%$ did not graduate.

Numerous attempts have been made from conventional methods to semi innovative ones that utilize media which suit the needs and capabilities of lecturers. Yet, the result is still not as expected.

By knowing the number of mathematical concepts that can be used in the field of mechanical engineering, researcher is interested to give lectures in other ways, namely by using information and communication technology (ICT). The development of ICT in education is getting rapidly. This is in line with the opinion that "the world is changing, as well as community and teaching; everything has changed" [2]. Education and technology must in accordance with the development in order to achieve success.

One of the technologies able to support the learning process is a classroom blog. Blog became increasingly popular in Indonesia, since a lot of people became famous only because the hobby of writing blog. Research on classroom blog is already conducted in several subjects, such as in [13], [14], [15]. Reference [3] stated that the use of media classroom blog has improved students' comprehension of the ICT concept.

Through classroom blog, students can express themselves by writing what they think. In addition, based on a preliminary research, students and teachers already acquainted with what a blog is. Most of them had active accounts either blogspot.com or Wikipedia.

Based on the above explanation, the researcher needs to develop a media and a learning implementation of classroom blog to improve students' comprehension of mathematical 
engineering. Classroom blog is one medium that presents material visually, which includes one of the hypermedia. Research of Schade [4] showed that people's memory who read by themselves is $\pm 1 \%$. This memory can be upgraded to $25-30 \%$ through television, while the use of hypermedia can improve memory as much as $60 \%$.

\section{LITERATURE REVIEW}

\section{A. Classroom Blog}

Blog derives from the word web blog which means internet (web) and note (log). Blogs can be literally defined as the diary entry, written and published on the internet. Among the earliest definition of blog was stated by Rebecca Blood, the owner of the blog www.rebeccablood.net and the author of The Webblog Handbook. Blog is a web page with the latest posts in which the contents placed on the top and updated frequently, sometimes several times a day. There is often a list of links on the content which refer to similar pages. According to The Cannon-Webster dictionary, "Blog is the term as an online personal journal that houses reflections, comments, and hyperlinks." Thus, the blog is a personal online journal contains about self-reflection, comments and links.

The term of blog or blogging arose from the existence of the act of posting/logging on to an online journal. Most writers agree that the weblog is a frequently updated web site, consists of various posts, comments sorted in reverse date. It is difficult to explain what weblogs are. The difficulty is due to the fact that the blog is filled with goals, usage and different writing styles. Yet, only one thing is the same i.e. the form (in the form of blogs).

Today, weblogs are also utilized for education which commonly called Classroom Blog, especially at the level of higher education, for example, the University of Iowa, Beras University and RMIT University in Melbourne. They are using classroom blog as a learning media. Many weblogs are written informally, and often depicts the experiences of the author-the result of thinking that reflects the self of the author.

Classroom blogs can be used by teachers or lecturers to follow the learning process of the students either in the classroom or outside the classroom. Students can also make it as a lesson journal which contains materials learned and describes summaries of what they read, as well as making it an information center used as a reference to increase students' knowledge. By using Classroom blogs, students and teachers are able to build an interactive environment, analyze a topic raised, and send comments. Thus, teachers can assess the active role of students in the learning process either in the classroom as well as outside.

\section{B. The Comprehension Ability}

Reference to [5], there are three aspects assessed in Mathematics. Those are concept understanding, reasoning and communication, as well as problem solving. These three aspects can be assessed by using a written assessment, performance assessment, product assessment, project assessment, or portfolio assessment.

As for the criterion of the three aspects are stated in TABLE I:

TABLE I. DESCRIPTION OF COMPREHENSION ABILITY

\begin{tabular}{|l|l|}
\hline Comprehension aspects & Indicators \\
\hline Concept comprehension & $\begin{array}{l}\text { Concept restatement. } \\
\text { Object classification according to certain } \\
\text { natures. } \\
\text { Set an example and non example of the } \\
\text { concept. } \\
\text { Present a concept in various forms of } \\
\text { mathematical representation. } \\
\text { Develop a necessary or sufficient condition of } \\
\text { the concept. } \\
\text { Use, utilize and select a certain procedure or } \\
\text { operation. } \\
\text { Apply a concept and algorithm of problem } \\
\text { solving. }\end{array}$ \\
\hline Reasoning & $\begin{array}{l}\text { Present a mathematical statement in the } \\
\text { forms of verbal, written, picture and diagram. } \\
\text { Submit hypothesis. } \\
\text { Conduct mathematical manipulation. } \\
\text { Draw conclusion, compile evidence, and give } \\
\text { reason or evidence toward validity of } \\
\text { solution. } \\
\text { Draw conclusion of the statement. } \\
\text { Check the validity of argument. } \\
\text { Discover pattern or nature of mathematical } \\
\text { symptom to make a generalization. }\end{array}$ \\
\hline $\begin{array}{l}\text { Show problem understanding. } \\
\text { Organize data and select relevant information } \\
\text { in problem solving. } \\
\text { Present problem in various mathematical } \\
\text { forms. } \\
\text { Select an approach and method in problem } \\
\text { solving correctly. } \\
\text { Develop a strategy in problem solving. } \\
\text { Create and interpret a mathematical model of } \\
\text { irregular problem. }\end{array}$ \\
\hline
\end{tabular}

Understanding means absorb a material taught. In the great dictionary of Indonesian Language, understand means comprehend precisely, whereas the concept means a draft. While in mathematics, the concept is an abstract idea that allows one to classify an object or event. So concept comprehension is the precise understanding of a draft or abstract ideas.

According to [6], comprehension is a person's ability to understand or comprehend something after it is known and remembered. In other words, comprehension is understanding about something and able to see it from a different standpoint. A learner is said to understand something if he/she could provide an explanation or give a more detailed description by using his/her own words. Comprehension is a level of thinking ability that is higher from memory or recitation.

In this research, the results are obtained based on the test results of students' comprehension concepts. According to the Ministry of Education and Culture [7], "the assessment of students' development includes in the indicator of concept comprehension ability as a result of learning math, such as: 1) Concept restatement, 2) Classify objects according certain natures, 3) Set examples and non examples of the concept, 4) Present concept in various forms of mathematical 
representation, 5) Develop a necessary or sufficient condition of the concept, 6) Use, utilize and select certain procedure or operation, and 7) Apply the concept.

The optimal level of concept comprehension occurs because learning is directed to establish a meaningful understanding, where the alignment experience and new knowledge exist in students' cognitive framework. According to [8], "comprehension means knowing about something and can see it from a different standpoint. It means that students are said to understand something if he/she can give a detailed explanation about something he know with his/her own words."

Reference to Bloom in [9] divides concept comprehension ability into 3 indicators: 1) Translation: Reference [10], translation comprehension (the ability to translate) is the ability to understand an idea expressed in other ways from the original statement known in advance. The ability to translate is a transition from concept to the language itself, or a transition from abstract concepts to a model or a symbol to be learned. 2) Interpretation: According to [10], interpretation comprehension (the ability to interpret) is the ability to understand recorded, altered, compiled material or ideas in other forms. For example in the form of charts, concept maps, tables, symbols, and vice versa. If the ability to translate means to change in portions, the ability to interpret includes unification and realignment. In other words, it is to connect the earlier parts with the next ones. 3) Extrapolation: According to [10], extrapolation comprehension (the ability to predict) is the ability to predict the available tendency according to certain data by expressing its consequence and implication in line with condition of being described. Thus, it is not only to remember but also to be able to re-express into another form which is easily understood, interpreted as well as applied.

Based on the advantage of classroom blog, this research would have revealed whether the use of a classroom blog media can enhance the ability of students' concept comprehension or not compared to the conventional one.

Research on the effectiveness of the use of Student Centered Learning-based Classroom Blog learning method to improve student learning Outcomes in High School had been conducted by [11] and the results showed that the learning outcomes of students increased.

\section{RESEARCH METHOD}

\section{A. Research Design}

To develop classroom blog use the principle of interactice learning software development in education [12] such as: (1) analysis, (2) design, (3) development, (4) implementation, and (5) testing or assessment from the user aspect, learning environment, curicula, protopype, and system completeness.

1) Analysis Stage

Aims to develop software, analysis of software and hardware needs, analysis of material and completeness features of software produced are established in this stage.

2) Design Stage
The stage includes elements establishment needed in the software which will be developed according to learning design. The design process of learning software developed includes 2 aspects, namely the aspect of Instructional Design and the aspect of learning content which will be given.

3) Developing Stage

Based on the learning design and storyboard which have been made, the software will be next developed as to create a prototype of learning software. Material, evaluation, animation, navigation, etc are integrated into program code.

After completing the development of software, judgments from expert are conducted by using series of multimedia software assessment. The assessment toward learning software includes the assessment of text, graphics, sound, animation and learning activity inside.

4) Implementation Stage

Software and units developed as well as prototype created then implemented during this stage. The implementation of interactive learning media software development is adjusted to the learning model applied. Students as user are able to use it as creative and interactive as possible through individual approach. The software developed obtains material from books, experience, environment, teachers, the experience of the user him/herself or urban stories. Thus, students are motivated to do Arithmetic and their curiosity increased.

5) Testing Stage

To find out the advantage as well as the disadvantage of the software developed, an assessment is conducted. Software improvement and refinement need to be carried out in order to be perfect.

The assessment stage is a stage which aims to find out the suitability of software in the learning program. The emphasis of assessment such as in computer literacy, learning material literacy and students' motivation are specified.

An advanced research methods used in this research was quasi experiment method with Non equivalent pretest, post test, and control group design. The design selection is in accordance to what will be conducted, i.e., to develop a classroom blog media continued with a limited implementation in the classroom by utilizing classroom blog media.

The research design will be as follow:

Description:

\begin{tabular}{|l|l|l|}
$\mathrm{O}_{1}$ & $\mathrm{X}$ & $\mathrm{O}_{2}$ \\
\hline
\end{tabular}

O1: Pre-test conducted to find out initial ability of students.

$\mathrm{X}$ : classroom blog media

O2: Post-test conducted to find out students' concept comprehension ability by using classroom blog. 


\section{B. Techniques of Collection and Data Analysis}

The technique of data collection is conducted in two ways: by doing a test before and after learning and distributing questionnaire, while the data analysis conducted consists of a prerequisite test, hypothesis test and questionnaire data analysis. Prerequisite test includes data normality test and homogeneity test, the hypothesis test and the gain normalized index. For the calculation, researcher uses SPSS 16.0 software program for windows, while data analysis uses Likert scale formulas.

\section{RESEARCH RESULT}

\section{A. The Development of Classroom Blog}

Stages taken in the development of classroom blog include: analysis of the needs, both software or hardware, planning, development and testing.

1) The Analysis stage: At the stage of analysis, a review carried out toward a necessity planning of hardware, software, and content that would be shown in the development of classroom blog. Since classroom blog which would be developed was a blog designed to appeal lecture, the researcher chose light software, which size was not too big and free, and easy to use. Therefore, in developing the blog the researcher used the latest version of Word press, i.e. Word Press 2.5 Release Candidate Edition August 27, 2014. Before installing word press to be developed into a blog, the researcher made a domain first. The domain given by the Directorate of ICT of Indonesia University of Education is: http://classroom-blog.staf.upi.edu/. After the domain retrieved then software installation of word press conducted.

The next stage was to analyze the display of the blog that will be developed. The stages are: the disposal of a suitable and simple theme, which structure is easy to understand and looks good.

The next step is to analyze the hardware. Basically the classroom blog developed worked almost in all hardware platforms used. Connected to the internet connection is the most important thing. Thus, no special hardware specifications are used, other than web browser, MS Office, pdf reader, flash player, and audio. Next is the analysis of the material presented in a classroom blog. The material presents on classroom blog is basic mathematical techniques, given on the semester of 2014/2015. Starting from the basic number, sets, relations and functions, matrix, plane, probability theory, limit, as well as derivative and integral. File formats that can be opened by the student are doc, docx, ppt, pdf, and flash animation files. The materials will be uploaded every session as needed. Next, the exercises are published gradually.

2) The Design stage: After analyzing the necessity in developing classroom blog, a flowchart is designed from the menu. The flowchart is seen on Figure1.

The menus of classroom blog are:

\section{- Homepage}

Initial display of classroom blog is presented, which presents instructions of blog usage, lecture's description, task collection instruction, login and chat.

- Lecture

It presents material given, started from the first lecture into the final one. The material uploaded is in the format of doc, docx, ppt, swf and pdf.

- Task

It presents tasks conducted by students and should be uploaded through classroom blog.

- Student's Grade

It presents students' grade started from task, quiz, first half exam, final exam and final grade.

- About

It presents classroom blog.

- Profile

It presents students' profile of Educational Department of Technical Machine of Indonesia University of Education.

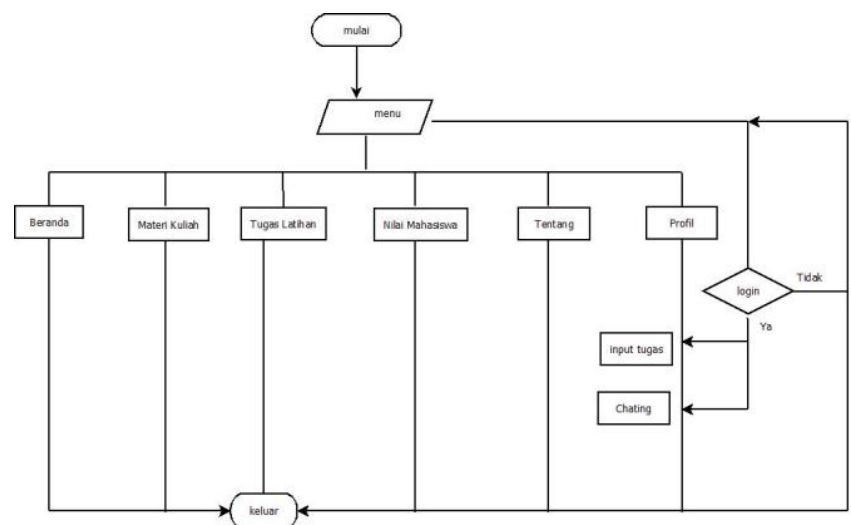

Fig 1. Flow chart of classroom blog

3) Development stage: The following is the display of classroom blog developed.

The display of classroom blog begins with homepage.

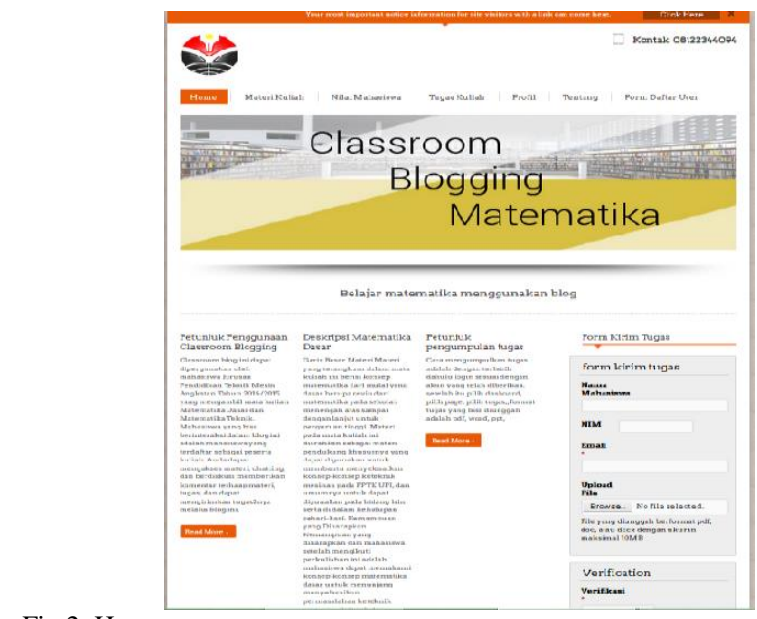

Fig 2. Homepage 


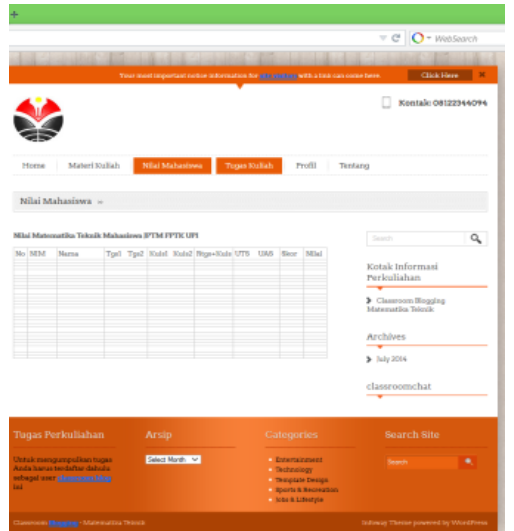

Fig 3. Lecture

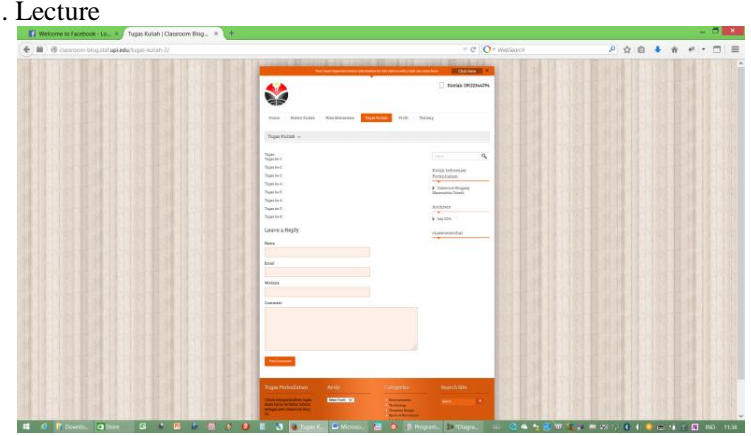

Fig 4. Students' Grade

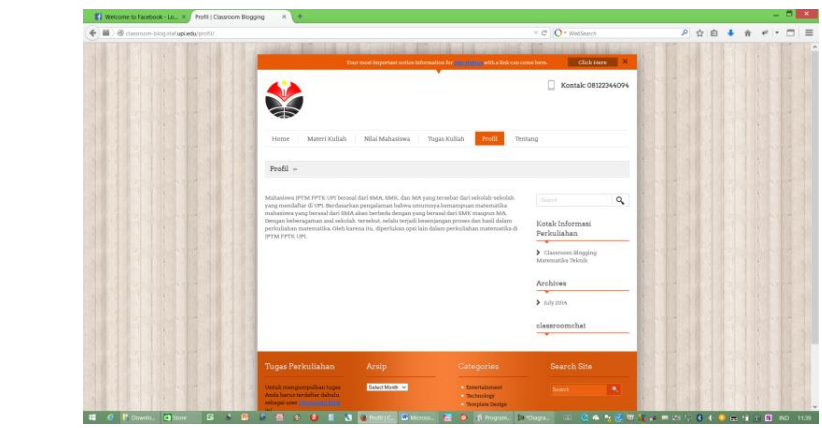

Fig 5. Task

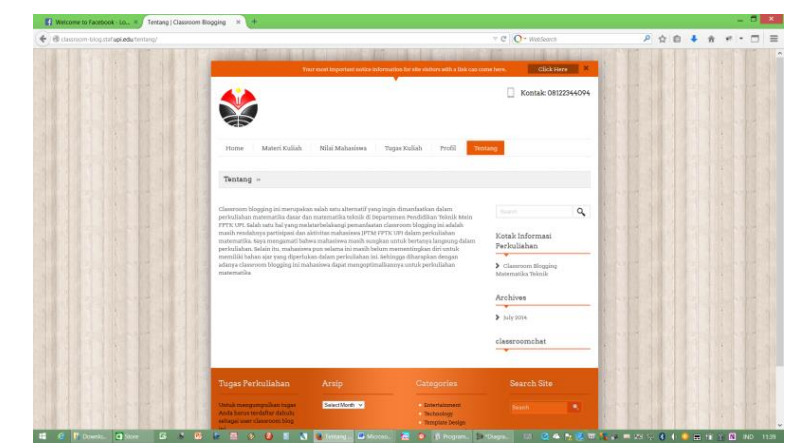

Fig 6. About

4) Implementaion stage: The implementation stage has been conducted in September 2014 for 8 meetings.
5) Testing stage: Before implementing classroom blog on lecturing activity, an assessment has been conducted by expert. The assessment involves lecturer of ICT subject and media learning expert. The process conducts through expert judgment comprehensively. It shows a good grade especially in the aspects of feature and visual design, information comprehensiveness, ease find website, task, discussion forum and access speed.

6) Implementaion stage: After the researcher conducted a preparation stage, the next stage was implementation. The implementation stage conducted is started from the initial semester of 2014/2015 which used 1 class. The implementation carried out during lecturing and after. Students might use the facility available anytime and anywhere. They are free to download material, give comments and chat with the lecturer.

a) Pre test: Pre-test are conducted in experiment class to measure the initial ability of students. The implementation itself conducted on the first meeting with the allocation time for 2 credit hours and 5 questions of description.

b) Lecturing Activity: The implementation of lecturing activity is conducted for 7 meetings. Students are freeto use their utilizing classroom blog. The materials to be used are materials which compatible with syllabus.

c) Post test: Post test conducted simultaneously with first half exam in the semester of 2013/2014 during lecturing activity. The allocation time is about 2 credit hours and 5 questions of description.

\section{Data Analysis of Research Result}

7) Data Analysis: As explained in the previous chapter, the sample of the research is 38 students of Educational Department of Technical Machine of Indonesia University of Education.

The data result of pre-test is analyzed to measure the initial ability of students' concept comprehension before lectures process initiated. Besides, it is also conducted to find out the homogeneity between the two classes. Here is the data analysis of descriptive statistics of pre-test between the group of experiment and control.

TABLE II.

DESCRIPTIVE STATISTICS DATA OF PRE-TEST AND POST TEST

\begin{tabular}{|c|r|r|r|r|r|}
\hline & \multicolumn{1}{|c|}{$\mathrm{N}$} & \multicolumn{1}{c|}{ Min } & \multicolumn{1}{c|}{ Max } & Mean & Std. Dev \\
\hline Pre-test & 38 & 5.0 & 55.0 & 35.4 & 13.1 \\
\hline Post-test & 38 & 22,0 & 59,0 & 37,2 & 15,3 \\
\hline
\end{tabular}

Based on TABLE I, the data of pre-test obtained showed that 55 are the highest score and 5 are the lowest. The mean is 35.4 and standard deviation is 13.1 , while the highest score in the post test is 59 and 22 as the lowest, the mean is 37.2.

The above data has not given any conclusion about the initial ability of experiment class. Therefore, normality test and homogeneity test were conducted by using KolmogorovSmirov test since the sample is less than 50. A manual in decision making by using significance standard $5 \%$ showed 
that both pre-test and post test indicate a good result. Samples which are not tested originated from population of un-normal distribution. Thus, similarity test of two non parametric mean is conducted (Mann Whitney).

TABEL II. THE RESULT OF MANN WHITNEY DATA PRE-TEST AND POST TEST

\begin{tabular}{|c|r|}
\hline & \multicolumn{1}{|c|}{ Student comprehension ability } \\
\hline Mann-Whitney U & 328.500 \\
\hline Wilcoxon W & 1231.500 \\
\hline Z & -6.638 \\
\hline Asymp. Sig. (2-tailed) & .025 \\
\hline
\end{tabular}

Based on TABLE II, the statistics testing of Mann Whitney, the significance value of researched group (0.025) was less than $\alpha=0.05$. Thus, $\mathrm{H}_{0}$ was rejected. It means that there is difference in the ability of students' concept comprehension before and after classroom blog implemented. The same result seen as homogeneity test was conducted in TABLE III. Based on the hypothesis test of Lavene, the value of $F$ count on post test with equal variance assumed was 3.9. The significance value (Sig.) of post test was 0.003 . Based on the criterion of decision making, the significance value (0.003) $<\alpha(0.05)$ so that $\mathrm{H}_{0}$ rejected or both variants of population was not equal (equal variances not assumed). The result of Lavene's test also showed that both variants of population was not equal (equal variances not assumed).

TABEL III. LEVENE'S TEST OF EQUALITY OF ERROR VARIANCES ${ }^{A}$

\begin{tabular}{|r|c|c|c|}
\hline F & df1 & df2 & Sig. \\
\hline 3.897 & 18 & 19 & .003 \\
\hline \multicolumn{3}{|c|}{ a. Design: Intercept + posttest } \\
\hline
\end{tabular}

The normalized gain level was counted to measure the improvement of comprehension ability before and after classroom blog implemented. Gain index was obtained from the division of post test minus pre-test by reducing the ideal maximum value with pre-test.

TABEL IV. OUTPUT OF GAIN INDEX

\begin{tabular}{|l|c|c|c|c|c|c|}
\hline \multicolumn{7}{|c|}{ Descriptive Statistics } \\
\hline & $\mathrm{N}$ & Min & Max & Mean & \multicolumn{1}{c|}{ Std. Dev } & Variance \\
\hline gain & 44 & .00 & 8.00 & .6895 & 1.19135 & 1.419 \\
\hline
\end{tabular}

Based on the data on TABLE IV, mean of gain index of researched group of 0.69 was seen by having maximum gain index 8 and minimum index gain 0 . The standard deviation obtain for each group was 0.69 .

According to the data description above, the mean of gain index of researched group had a sufficient difference. Thus, the improvement of students' concept comprehension ability by implementing classroom blog had a medium category.

8) The Analysis Data of Questionnair:The questionnaire contained 25 questions that should be answered by students after classroom blogoccurred. The following are students' response of classroom blog.
The answer of the questionnaire does not affect pre-test and post test. It also functions as supported data of decision making in answering research problems.

In general, students' response toward classroom blog showed a positive result since it was considered interesting, easy to interact and exciting. They even felt satisfied as they were able to discuss with the lecturer. The learning itself became more effective, easier and fun. Thus, it could be concluded that the display of classroom blog and students' interest are positive.

TABLE V. STUDENTS' RESPONSE OF CLASSROOM BLOG

\begin{tabular}{|c|c|c|c|c|c|c|}
\hline Variabel & Indikator & Nomor & VA & A & NA & VNA \\
\hline $\begin{array}{c}\text { classroom } \\
\text { blog }\end{array}$ & $\begin{array}{c}\text { Menu and } \\
\text { home }\end{array}$ & $1,2,3$ & $11 \%$ & $79 \%$ & $10 \%$ & $0 \%$ \\
\cline { 2 - 7 } & $\begin{array}{c}\text { The } \\
\text { completteness } \\
\text { of facilites } \\
\text { (chatting, } \\
\text { upload, dan } \\
\text { download } \\
\text { course) }\end{array}$ & $4,5,23,24$ & $21 \%$ & $67 \%$ & $10 \%$ & $2 \%$ \\
\cline { 2 - 7 } & Navigation & $6,7,8$ & $12 \%$ & $86 \%$ & $2 \%$ & $0 \%$ \\
\cline { 2 - 7 } & User easiness & $9,10,11$ & $7 \%$ & $93 \%$ & $0 \%$ & $0 \%$ \\
\cline { 2 - 7 } & Relevance & 12,25 & $24 \%$ & $69 \%$ & $5 \%$ & $2 \%$ \\
\hline \multirow{7}{*}{ interest } & Attention & 13,15 & $33 \%$ & $62 \%$ & $5 \%$ & $0 \%$ \\
\cline { 2 - 7 } & Confidence & $14,16,17$ & $29 \%$ & $64 \%$ & $7 \%$ & $0 \%$ \\
\cline { 2 - 7 } & Satisfaction & $18,19,20$ & $0 \%$ & $0 \%$ & $90 \%$ & $10 \%$ \\
\cline { 2 - 7 } & Relevance & 21,22 & $36 \%$ & $62 \%$ & $2 \%$ & $0 \%$ \\
\hline
\end{tabular}

Based on TABLE V, each statements on the questionnaire can be explained as follow: in terms of the development of classroom blogs it can be interpreted that: $79 \%$ students state that the classroom blog that is used has an easy menu structure, has a pleasing look, and does not make them bored, $67 \%$ of them state that the classroom blog is very supportive to be used in the engineering mathematical lecture and has many features that allow them to interact through a classroom blog, those features are chatting, uploading tasks, downloading teaching materials, knowing the students achievement results, and interacting with the lecturer. Furthermore, $86 \%$ of students state that the structure of the navigation system, menus, and flow chart are suitable for the needs of classroom blogs lectures, $93 \%$ of students state classroom blogs are easy to use, 69 of which states classroom blogs relevant to the needs of lectures by utilizing technology. Meanwhile, regarding to the interest of the students in the use of classroom blogs, it can be interpreted as follows: $62 \%$ of students state that they disagree with using classroom blogging, they are able to pay attention to the materials easily, as many as $64 \%$ of students express an agreement that classroom blogs implementation can bring confidence to ask questions to the lecturer any time they want, $90 \%$ of students disagree that they are not satisfied by having classroom blogging, and $62 \%$ of students agree that the implementation of classroom blogs is relevant with their needs in learning engineering mathematics. 


\section{DISCUSSION}

The research aims to analyze classroom blog implementation in improving the ability of students' concept comprehension on basic/technical mathematics of Educational Department of Technical Machine of Indonesia University of Education. Based on the result study, the improvement of students' concept comprehension ability by implementing classroom blog increased more than before though it was not really significant. It was proven by the analysis result of pretest and post test. There was a difference between the initial concept comprehensions of student' ability and the final one by using significance value $(\alpha) 5 \%$. It means that the improvement was on the medium level.

After conducting the lecturing activity for 7 meetings, classroom blog could improve students' ability of concept comprehension. From the test result of post test data (based on mean), the significance value of 0.025 was obtained, smaller than 0.05. Thus, it was not homogeneous. In other words, there was a slight difference between the ability of concept comprehension before and after classroom blog implemented.

Besides, to find out how much the improvement was the data analysis of gain normalized index was conducted. As for the acquisition of gain index of researched group was 0.69 which included in medium category. In conclusion, classroom blog improved students' ability of researched group in concept comprehension.

The improvement obtained by students of researched group was possible since students were not solely passive in receiving material. Yet, they participated actively and had motivation to receive the lecturing activity designed by lecturer. The stages might be systematic in each meeting though at first they felt confused and rather indifferent. Yet, for the next meeting, they began to understand technically and pleased during the learning process.

In general, the obstacle encountered during classroom blog implemented were the time allocation which deemed to be inadequate since discussion and presentation were limited, so that students had difficulties to conduct it well and smooth.

Limited internet was also an obstacle during the research process. The more users, especially when they conducted chatting, the slower the discussion got. It was possibly due to capacity overloaded of the internet. In the end it hindered the learning process as the speed of the internet was getting slower.

Students' activity during learning process became more active, conducive, interesting and pleasant since they did not hesitate to ask.

\section{CONCLUSION}

a) The development of classroom blog was in accordance with the regulation of software development in general, i.e. through the stages of necessity analysis, design, development, trial and limited implementation. Each stage was adjusted to the necessity of classroom blog development of basic/technical mathematics.

b) Based on the implementation result, there was an improvement though it was slightly medium (seen from gain index)

c) .After implementing classroom blogging, students' responses were quite favorable. The response presented students' reactions toward classroom blog development and their interest/motivation in basic/technical mathematics.

\section{REFERENCES}

[1] D, Rohendi, D and J. Dulpaja. "Connected Mathematics Project (CMP) Model Based on Presentation Media to the Mathematical Connection Ability of Junior High School Student", IISTE.org, Journal of Education and Practice, USA, June, 2013.

[2] Ruseffendi E.T, "Pengantar Kepada Membantu Guru Mengembangkan Kompetensinya dalam Pengajaran Matematika untuk Meningkatkan CBSA”. Bandung: Tarsito, 1991.

[3] D.Rohendi, Lida, Ayu Mentari, and Saepudn, Asep, "Developing Classroom Blogging Media for Increasing ICT Student Comprehenssion Concept Ability". Journal Technodik. Jakarta: Kemendikbud, 2013.

[4] Munir, "Aplikasi Multimedia dalam Proses Belajar Mengajar". Jurnal Mimbar Pendidikan XX(3). Bandung : UPI Press, 2013.

[5] Zulaiha, "Definisi Pemahaman Konsep". 2006, http://ahlidefinisi.blogspot.com/2001/103/ definisi-pemahaman-konsep.html. Diakses pada tanggal 13 Desember 2011

[6] Sudijono, Anas, "Pengantar Evaluasi Pendidikan. Edisi 7". Jakarta: Raja Grafindo Persada, 2007.

[7] Jannah, Miftahul., "Kemampuan pemahaman konsep Siswa Kelas VII SMP Negeri 2 Tanjung Brebes Dalam Pembelajaran Matematika denganPendekatan Realistic Mathematics Education (RME) pada Sub MateriPokok Bahasan Persegi Panjang dan Persegi Tahun Pelajaran 2006/2007", Skripsi FMIPAUniversitas Negeri Semarang, 2007.

[8] Sujiono, "Strategi Pembelajaran Berorientasi Standar Proses Pendidikan”, Jakarta:Kencana Perdana Media Group, 2001.

[9] Kusmana, Agus, “Aspek-aspek Pemahaman Konsep”, 2010, [Online]. Tersedia : http://aguskusmanago.blogspot.com/2010/04/aspek-aspekpemahaman-konsep.html [04 Januari 2013]

[10] Subiyanto, "Evaluasi Pendidikan Ilmu Pengetahuan Alam", Jakarta: Proyek Pengembangan Lembaga Pendidikan Tenaga Kependidikan, 1988.

[11] Maryam, dkk, "Efektivitas Penggunaan Metode Pembelajaran Student Centered Learning Berbasis Classroom blog untuk Meningkatkan Hasil Belajar Siswa SMA", Skipsi: UPI Bandung, 2011.

[12] Munir, "Kurikulum Berbasis Teknologi Informasi dan Komunikasi", Bandung: Alfabeta, 2010.

[13] Munir, "Kurikulum Berbasis Teknologi Informasi dan Kounikasi", Bandung: SPS Universitas Pendidikan Indonesia, 2008.

[14] JB Williams, J Jacobs. "Exploring the use of blogs as learning spaces in the higher education sector", Journal of Educational Technology, 2004.

[15] Duffy, Peter D. \& Bruns, Axel, "The Use of Blogs, Wikis and RSS in Education: A Conversation of Possibilities". In Online Learning and Teaching Conference 2006, 26 Sep. 2006

[16] D Huffaker, "The educated blogger: Using weblogs to promote literacy in the classroom", First Monday Journal, 2004. 
